\title{
The Perception of Fourth Year Pharmacy Student of UIN Syarif Hidayatullah Jakarta Towards the Pharmacy Profession
}

\author{
Yardi, Nelly Suryani \\ Pharmacy Department \\ Faculty of Medicine and Health Sciences, State Islamic University \\ Jakarta, Indonesia \\ yardi@uinjkt.ac.id
}

\begin{abstract}
Pharmacy profession (pharmacist) is one of the health profession which has high responsibility for the patient health and safety. In doing this responsibility, a pharmacist should serve their patient directly. Anybody who choose the profession should aware and run it with all their heart and sincerely. This study aimed to describe the perception of fourth year pharmacy student toward the pharmacy profession that they choose. A questionnaire survey that explored their attitudes and views towards the Pharmacy profession was chosen for this study. The result showed that although at the beginning the choice to study in pharmacy was not the first one for a large number of students, as time went by, most of them felt satisfy to spend their life in studying pharmacy. Most of them knew very well about the scope of pharmacy profession. Most of Pharmay students chose the subject for their final research which related to the work field that they like to do after graduation. The $17.81 \%$ of the pharmacy students would like to work at the pharmacy service centre (i.e hospital and community pharmacy) that directly serve the patient while others chose the other work filed. Pharmacy education should consider the currikulum which meet the work field need and that enhance the student competence.
\end{abstract}

Keyword : pharmacist; pharmacy profession; pharmacy student; perception; community pharmacy

\section{INTRODUCTION}

As it is stated in Indonesian statue that Pharmacist is one of health profession besides physician, nurse, clinical phycologist, midwife and others[1]. Pharmacist has an important role in assuring that patient get the maximum benefit from medicine they take. There are two main pharmacist responsibilities in the health care service i.e managerial and clinical pharmacy service[2][3]. In Indonesia to be a pharmacist, a student must complete the 5 years course, 4 years for academic and 1 year for profession degree. Five years course is mostly conducted in classroom or laboratory whereas one year profession course in classroom and in the form of field study such as hospital, pharmacy industry, community pharmacy, public health centre. To complete the study in pharmacy, student have to give their full effort. There are many practical subjects that they should follow that need longer time compared to classroom subject[4].

Some mass medias reported that pharmacy is included in the ten most difficult major to study[5] [6]. As one of the most difficult major, everybody who want to study in it needs to give their hard and serious effort in order to get the best study outcome. Students need to realize what they have choosen for their next career and what to prepare for that. As one of the health care team member after they graduate from the course, pharmacist need to do their job and responsibility with all their heart and soul where working with these are needed for the confortableness of patient.

Research relating to pharmacy student is rarely conducted in Indonesia. In other side, this kind of reserches has been conducted in america in much number[7][8][9][10]. This study aimed to describe the perception of fourth year pharmacy student toward the pharmacy profession that they choose

\section{METHODS}

This is the descriptive research design. Data were collected through survey by giving questionnaire to respondent. Questionnaire consist of 13 questions that explore the view and perception of respondent. Respondent were all fourth year pharmacy student in pharmacy department of faculty of medicine and health science, UIN Syarif Hidayatullah Jakarta, Indonesia. Question items were largely in closed-question format to maximize the response rate. Several open-question were also include in the questionare.

Questionare was adapted from Yogesh Joshi and Reena Pant by modification [11]. Questions which in the questionaire were as follows : the responden sex, decision 
behind their choice to study in pharmacy, their knowledge about the pharmacy before their decision, the order of their choice in selecting pharmacy, Their satisfaction after ddecision, their most favorite profesion biside pharmacist, their knowledge about the scope of pharmacy profession job filed, their plan after graduation from pharmacy, the choice for their final research task, the reason behind their choice for the final research task and their desire about the study method. Data were analyzed with univariate analysis to describe the variables.

\section{RESULT}

All fourth year student of pharmacy course answered the questionaire. Women were $82.2 \%$ from the total of 73 students. Fig. 1 showed the decision behind students choice to study in pharmacy. The $62 \%$ of them said that to study in pharmacy were their own choice while $33 \%$ of them said that their family member influenced their choice to study in pharmacy and the rest were influenced by their friends, school teacher and others. Fig. 2 showed that $89 \%$ of students admitted that they have ever heard about pharmacy before they decided to study in pharmacy.

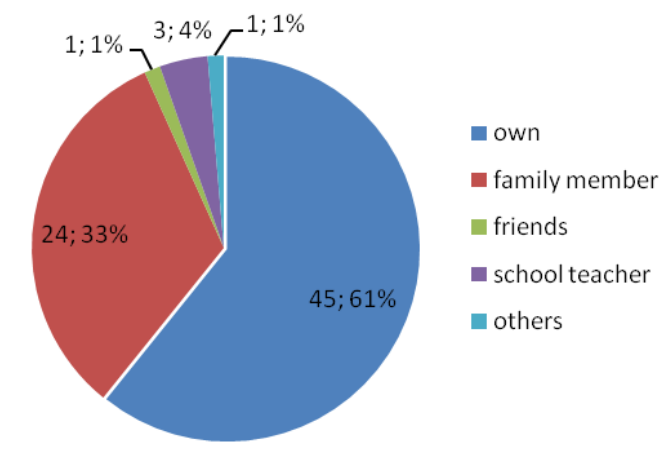

Fig. 1 The decision behind the student choice to study in pharmacy

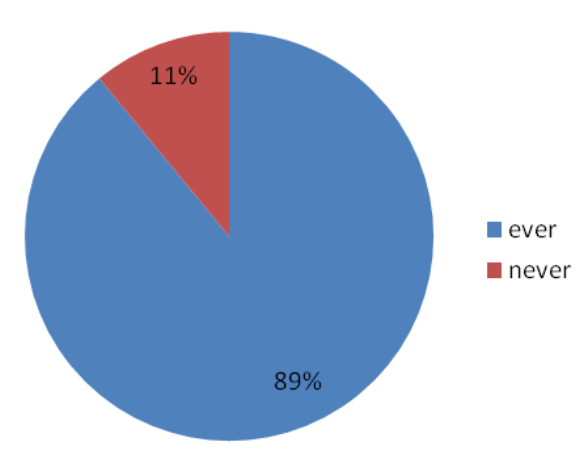

Fig. 2 Student answer wheather they have ever heard about pharmacy before their decision to study pharmacy
Student preferred choice when they followed the national test to enroll in university can be seen in fig.3. Forty one percent of students said that to study in pharmacy was their first choice. In bigger number i.e $47 \%$ of students said that studying in pharmacy was their second choice. The rest $(12 \%)$ of students answered that it was their third choice. Fig.4 showed that after three and a half year studying in pharmacy, $73 \%$ of student felt satisfied. The unsatisfied student preferred to choose the other study program which can be seen in table 1 .

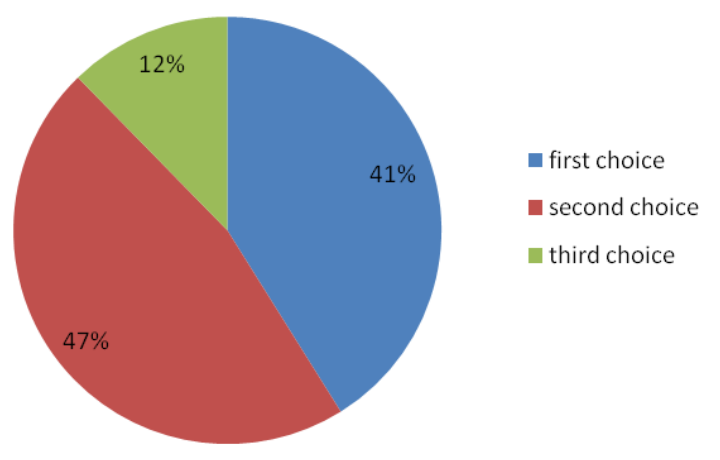

Fig. 3 Student order of choice to study in pharmacy

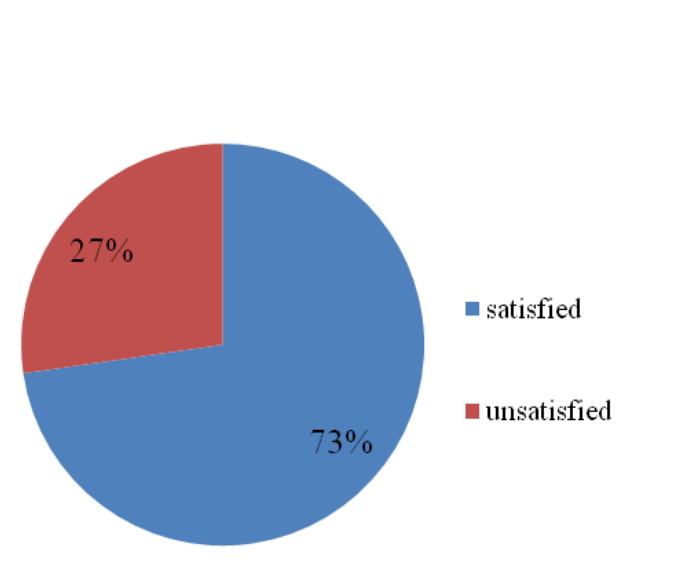

Fig. 4 Student satisfaction after three and a half years study in pharmacy

TABLE 1. STUDENT PREFER TO STUDY RATHER THAN PHARMACY DEPARTMENT

\begin{tabular}{|l|l|}
\hline No & Department (study program) \\
\hline 1 & Biology \\
\hline 2 & Dentistry \\
\hline 3 & Public health \\
\hline 4 & Social \& bisnis \\
\hline 5 & Chemistry technic \\
\hline
\end{tabular}

For the question " do the student know well about the scope of pharmacy profession work fiel". The student said that they knew the scope (97\%) as can bee seen in fig.5. Table 2 showed that $17 \%$ of fourth year pharmacy student of UIN Syarif Hidayatullah Jakarta wanted to continue their study to the higher pharmacy education as well as to work in 
industrial pharmacy. Working in pharmacy service centre i.e hospital and community pharmacy were chosen by $17.81 \%$ of pharmacy student. None of them wanted to work in education field.

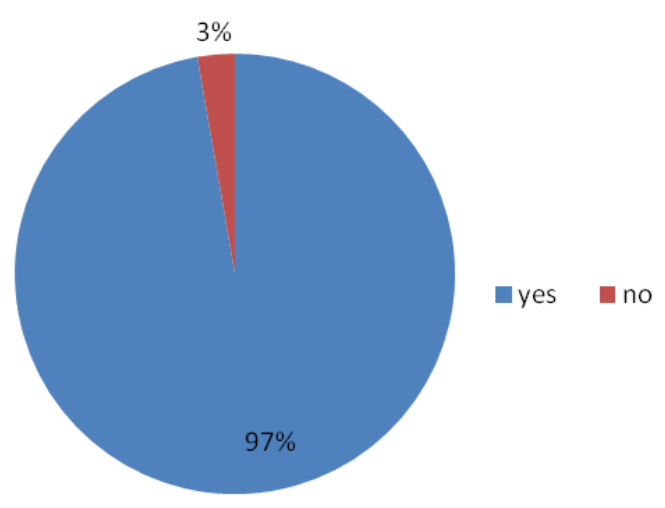

Fig. 5 Student knowledge on the scope of pharmacy profession workfield

TABLE 2. STUDENTS PLANNING AFTER GRADUATION FROM BACHELOR COURSE

\begin{tabular}{|c|c|c|c|}
\hline No & Description & Frequency & $\begin{array}{c}\text { Percentage } \\
(\%)\end{array}$ \\
\hline 1 & $\begin{array}{l}\text { Continuing to Higher } \\
\text { Pharmacy Study }\end{array}$ & 17 & 23.29 \\
\hline 2 & $\begin{array}{l}\text { Working in Industrial } \\
\text { Pharmacy }\end{array}$ & 17 & 23.29 \\
\hline 3 & $\begin{array}{l}\text { Working in Governmant } \\
\text { Office }\end{array}$ & 13 & 17.81 \\
\hline 4 & $\begin{array}{l}\text { Working in Pharmacy } \\
\text { Care Service (Hospital) }\end{array}$ & 10 & 13.70 \\
\hline 5 & $\begin{array}{l}\text { Working in Research } \\
\text { And Development }\end{array}$ & 8 & 10.96 \\
\hline 6 & $\begin{array}{l}\text { Continuing Study To The } \\
\text { Other Study Beside } \\
\text { Pharmacy }\end{array}$ & 5 & 6.85 \\
\hline 7 & $\begin{array}{l}\text { Working in Pharmacy } \\
\text { Service (Community } \\
\text { Pharmacy) }\end{array}$ & 3 & 4.11 \\
\hline \multirow[t]{2}{*}{8} & Working in Education & 0 & 0.00 \\
\hline & & 73 & 100,00 \\
\hline
\end{tabular}

As it can be seen in table 3, as much as $34.25 \%$ of pharmacy student chose pharmacy technology for the final research, followed by experimental pharmacology, natural chemistry, analytical chemistry, and others. Eighty nine percent of them said that they chose the topic which related to the work field that they plan to work after graduation. The reasons for student that did not want to choose the related subject were : planning to work in sociopreneur; the subject is interesting, proving something, entrepreneur, having no idea for the future work.
TABLE 3. STUDENTS DESIRE FOR THE FINAL RESEARCH

\begin{tabular}{|r|l|r|r|}
\hline \multicolumn{1}{|c|}{ No } & Description & Frequency & \multicolumn{1}{c|}{$\begin{array}{c}\text { Percentage } \\
\text { (\%) }\end{array}$} \\
\hline 1 & Pharmacy Technology & 25 & 34.25 \\
\hline 2 & $\begin{array}{l}\text { Pxperimental } \\
\text { Pharmacology }\end{array}$ & 13 & 17.81 \\
\hline 3 & Natural Chemistry & 11 & 15.07 \\
\hline 4 & Analytical Chemistry & 7 & 9.59 \\
\hline 5 & $\begin{array}{l}\text { Clinical Pharmacy } \\
\text { (Hospital) }\end{array}$ & 5 & 6.85 \\
\hline 6 & Microbiology & 5 & 6.85 \\
\hline 7 & Pharmacy Biology & 4 & 5.48 \\
\hline 8 & Community Pharmacy & 3 & 4.11 \\
\hline & & 73 & 100,00 \\
\hline
\end{tabular}

\section{DISCUSSION}

Study in pharmacy course is one of the most difficult one. There are so many subjects that related to chemistry, mathematics and science. Most people agree that these subjects are the difficult ones. In the other side, pharmacist profession in the last few decades face the role shift from product oriented to patient focus centre [10](12). Pharmacy curriculum in Indonesia as well as in Pharmacy department of UIN Syarif Hidayatullah Jakarta has its own system. It consist of two course i.e bachelor course for 4 years and profession course for 1 year [4][13]. There have been shifting in pharmacy curriculum. Newer curriculum is more oriented to patient but it's proportion is still less if compared to curriculum in developed country such as America [14]. Most of pharmacy institution in Indonesia still combine the pharmacy science and patient oriented pharmacy while in America, they have pharmacy science and pharmaceutical Doctor (Pharm. D) course. This means that pharmacy student in Indonesia has wide range of subjects to study. They have to learn about pharmacy science and pharmacy patient focus during the study. The student should consider this before they enroll to pharmacy department.

Many Students did not choose pharmacy by their own decision (39\%) as well as Pharmacy not as their first choice $(59 \%)$. This finding is different from what Nurwahidah reported that mostly student decided their choice in to study in social science education in Education faculty of UIN Syarif Hidayatullah Jakarta(15). Family member has superior influence for student in choosing their study above other factors. This finding is similar to Kristina Koo et al reported[16][17]. This group need to get good attention from the pharmacy department head. Supervisor lecture should guide them actively. They have to encourage that group by giving many informations and positive views about pharmacy. They have to be monitored during the study, especially at the beginning phase/semester to make them easily adapted and feel convenience to study in 
pharmacy in order to get good achievement during their study. They should be encourage to openly discuss about their problems.

Although at the first period, the number of students that do not chose pharmacy as their own choice neither their first choice, along with the time they became enjoy studying pharmacy which indicated by the number of student that felt satisfied $(73 \%)$. This may be caused by many reasons. This study did not explore them. The reasons may be as follow: student become well informed about pharmacy after they got many subjects during their study, supervisor lecture had guided them very well.

Pharmacy students which want to get career in pharmacy care centre (hospital and cummunity) is $17.81 \%$ whereas this work field are actually relevant to the position of pharmacist (pharmacy profession) as one of health profession that contact directly to patient. Other work fields are more relevant to pharmacy science. The student desire to work after graduation in hospital is similar from the real condition. Many hospitals in Indonesia are still lack of pharmacist[18]. In other hand the number of student which want to work in cummunity pharmacy is different from the real condition. Almost $50 \%$ pharmacist in Indonesia is registered as pharmacist in charge in community pharmacy[19].

\section{CONCLUSION}

Fourth years pharmacy student is well known about the scope of pharmacist profession career. They still need to follow wide range of pharmacy curiculum that accomodate pharmacy science and patient oriented pharmacy. Pharmacy education should consider the currikulum which meet the work field need and that enhance the student competence.

\section{REFERENCES}

[1] - Republic of Indonesia, " Indonesia statue on health profession number 36 (Undang-Undang RI No 36 Tentang Kesehatan)," 2009;I(2):1-57.

[2] - Ministry of health," Pharmacy service standard in community pharmacy number 73 ( Peraturan menteri kesehatan nomor 73 tentang standar pelayanan kefarmasian di apotek). Indonesia; 2016 p. $1-40$.

[3] - Health of health," Pharmacy service standar in publich health centre number 72 ( Peraturan menteri kesehatan nomor 72 tentang standar pelayanan kefarmasian di puskesmas)," Indonesia; 2016 p. 148.

[4] - State Islamic University UIN Syarif Hidayatullah, "Academic guidance of UIN Jakarta. [Internet]. jakarta; $2016 . \quad$ Available from: http://www.uinjkt.ac.id/wpcontent/uploads/2015/01/Pedoman-Akademik-20152016-UIN-Syarif-Hidayatullah-Jakarta.pdf
[5] - liputan 6. The sevent most difficult study major in Indonesia. 2016; Available from: http://citizen6.liputan6.com/read/2433531/7jurusan-kuliah-paling-sulit-di-indonesia

[6] Tab T. The most difficult majors in America [Internet]. 2017. Available from: https://thetab.com/us/2017/03/13/hardest-major62699

[7] F. Keshishian, B.P. Brenton, "Factors influencing pharmacy students' choice of major and its relationship to anticipatory socialization," Am J Pharm Educ. 2010;74(4):75.

[8] D.C. Anderson, M.C. Sheffield, A.M. Hill, H.H. Cobb, " Influences on pharmacy students' decision to pursue a doctor of pharmacy degree," Am J Pharm Educ. 2008;72(2):22.

[9] L.M. Savage, J.W. Beall, T.W. Woolley," Factors that influence the career goals of pharmacy students," Am J Pharm Educ. 2009;73(2).

[10] F. Keshishian, B.P. Brenton," Pharmacy students' perceptions of their curriculum and profession: Implications for pharmacy education," Pharm Educ. 2011;11(1):194-200.

[11] Y. Joshi, R. Pant," A Study To Evaluate The Perception Of Pharmacy Student's Towards The Pharmacy Profession. Int J Pharm Res. 2011;2(12):3114-7.

[12] C.K. By, P. Tand," The development of clinical pharmacy in Indonesia," Pharm J [Internet]. 2000;264(7098):817-9. Available from: http://www.pharmaceutical-journal.com/thedevelopment-of-clinical-pharmacy-inindonesia/20001584.article

[13] J.P. Soepomo," Variation Cummulative Credit Of Indonesian Pharmacy Course In Supporting The Promotion Of Rational Drug Use," Pharma. 2015;161-8.

[14] A. Hussain, M. Malik, S. Abdullah, "Review of Evolving Trends in Clinical Pharmacy Curriculum around the Globe,"American Journal of Pharmacological Sciences. 2017;5(1):1-7.

[15] Nurwakhidah," Factors that influence student decision in choosing social science education in Education faculty of UIN Syarif Hidayatullah Jakarta," 2014.

[16] K. Khoo, T.K. Ban, C.Y. Neng, B.K. Hooi, C.Y. Joan, "Student choices of choosing colleges and course of study in Penang," ABC Res alert. 2015;3(1):1-7.

[17] L. Agrey, N. Lampadan, "Determinant Factors Contributing to Student Choice in Selecting a University," J Educ Hum Dev. 2014;3(2):391-404.

[18] - Berita satu., "Ministary of health: Pharmacist number is only $20 \%$ of total hospital and public health centre," [Internet]. 2013 Apr; Available from: http://www.beritasatu.com/nasional/105947kemkes-jumlah-apoteker-hanya-20-dari-total-rs- 
dan-puskesmas.html

[19] Yardi, "The role of community pharmacist in cunducting pharmacy service standard in Ciputat," Indonesia. Med Islam; 2016;2 p.126-135 